\title{
Transformational Style of Leadership Sparks Great Economic Growth in the Kenyan SACCO Movement
}

\author{
Jossylyn Nzilani Mutua* Dr. Theresia Mutetei** ${ }^{* *}$ Dr. Cavens Kithinji*** \\ *Student Pan African University \\ ${ }^{* *}$ Research Associate and Adjunct Lecturer, Pan African Christian University \\ *** Registrar, Administration \& Planning, Lecturer Community Development, Pan African Christian University \\ DOI: 10.29322/IJSRP.11.01.2021.p10988 \\ http://dx.doi.org/10.29322/IJSRP.11.01.2021.p10988
}

\begin{abstract}
This article outlines how the transformational leadership style impacts organizational performance; the relationship between individual consideration and organizational performance (OP) in Kenya's Savings and Credit Co-operative (SACCO) movement. The study focused on Mwalimu National, Stima and Kenya Police SACCO Societies. It highlights that a transformational leader listens to each employee's concerns and needs, provides support, is empathic of each person's situation and background, portrays respect and trust to his followers positively and positively impacts OP. The findings from a study on the relationship between transformational leadership and organizational performance of Mwalimu National, Stima and Kenya police SACCO societies confirm that individual consideration is a transformational leadership (TL) element where management acts as a role model and displays a charismatic personality that builds trust with employers and customers who, in return, develop their confidence in the organization. The findings also confirmed a positive and significant relationship between the individual consideration and organizational performance of Kenya Police, Stima and Mwalimu National SACCO Societies (Sign. = $0.000,0.000$, and $0.004<0.05$ ). Therefore, the above results confirm a significant relationship between individual consideration and OP, compelling the adoption of transformational leadership style for better organizational performance and service delivery within the SACCO movement in Kenya, Africa and globally.
\end{abstract}

Index Terms- Leadership, Transformational leadership, individual consideration, organizational performance

\section{INTRODUCTION}

$\mathrm{T}$ ransformational leadership is vital in initiating change in organizations, groups, oneself and others by motivating followers to attain higher goals than what they intended or even more than what they thought was possible. The leaders set expectations for the followers and they typically achieve high performance. Statistically, transformational leaders have more committed and satisfied followers. They attain this status mainly because they empower followers (Raza, 2019). Regardless of ones' organizational position, transformational leaders engage in the following four elements: individual consideration, intellectual stimulation, inspirational motivation and idealized influence. Individual consideration as an element of TL is the management of an organization to determine and consider each employee's specific needs and desires and motivate them to grow and become fulfilled in their positions (Schieltz, 2019).

Organizational performance involves analysing a company's performance against its objectives and goals. It comprises of real results or outputs as compared with expected outputs. Organizational performance is how successful an organized group of people is with a particular purpose and how they perform a function to achieve successful outcomes (Louise, 2012). Globally, 30 years of research on leadership and many metaanalyses show that transformational leadership enables a wide range of performance outcomes, including individual, group and organizational level variables (Bass \& Bass, 2008). Global studies also show that organizations with transformational leadership styles are perceived as active (Cilliers \& Deventer, 2008).

Considering Mwalimu National, Stima and Kenya police SACCOs, the study sought to establish whether their performance is related to individual consideration as an element of transformational leadership style. The selection of these three cooperatives is justified because they nationally rank first, second and third respectively in terms of performance with over Kshs .30 billion in deposit liabilities for the years 2017 and 2018 (Mwaka, 2019). Besides their performance, the researcher also considered their national coverage and market share to establish whether there is any relationship between individual consideration and their performance. The objective of the study was to ascertain the relationship between individual consideration and organizational performance of Mwalimu National, Stima and Kenya Police SACCO Societies. This article is based on a research conducted.

Mwalimu National SACCO came into existence on $24^{\text {th }}$ October 1974 under the Co-operative Societies Act (Cap. 490, reviewed in 2004 as a SACCO Society). The SACCO customers by then were the employees of the Teachers' Service Commission (TSC) in post primary institutions, TSC secretariat and the personnel. It is the largest African SACCO with its membership drawn from all the teachers in Kenya (Mwalimu National SACCO, 2019). According to the 2013 Banking Supervision Report; Commercial Banks in Kenya are ranked based on their total asset and turnover. Mwalimu National SACCO ranks $21^{\text {st }}$ and $22^{\text {nd }}$ respectively. With a well established functional banking structure and a sound financial standing in place, the SACCO today has a membership drawn from all parts of this country (Central Bank of Kenya, 2013). These are the elements that determine the choice of this SACCO to establish whether the tremendous change and 
achievement are related to any transformational leadership style adopted by the management or not.

Stima Deposit Taking (DT) SACCO is licensed. It came into existence in 1974 with the sole mandate of uplifting its members' social economic well being. In April 2003, the SACCO introduced the Front Office Service Activity (FOSA) to offer banking services to its members. To date, the SACCO has nine branches: Nairobi (Parklands), Mombasa, Kisumu, Nakuru, Olkaria, Eldoret, Nairobi Central Business District (CBD), Embu and Kawi Centre (South C) (Stima SACCO Society Limited, 2019). Stima DT SACCO membership is from employees of several entities within the energy sector. These are Kenya Power \& Lighting Company Limited (KPLC), Kenya Electricity Generating Company Limited (KENGEN), Rural Electrification and Renewal Energy Corporation (REREC), Stima SACCO employees, Electricity and Petroleum Regulatory Authority (EPRA), Kenya Electrical Trade and Allied Workers Union. The retired staff of all the above organizations forms part of the membership. Stima SACCO recently opened its doors to the public; attaining a total membership of 117,000 members as of December 2018. The SACCO's management enhances members' socio economic status by mobilizing savings and affording them credit at fair and reasonable rates. Stima SACCO recently paid dividends and interest rebates at the rate of $14 \%$ and $10.7 \%$, making it the best provider of loan services in the country; the best among the registered SACCOs; the best provider of loan services and the best managed SACCO in the parastatal sector (Stima SACCO Society Limited, 2019).

Kenya Police SACCO came into existence on $20^{\text {th }}$ November 1972. Registration was done under the Co-operative Societies Act Cap 490 of Kenya's laws. The society started its operations in June 1973. It began to mobilize members' savings and provide affordable credit facilities. It began with a membership of 690 members. Currently, it has a total membership of 63,450 members with an asset base of Kshs. 30 billion and a loan portfolio of Kshs. 26 billion. The society revised its bylaws in 2018 and opened its common bond where a person of either gender is eligible for membership. A member in the possession of the listed attributes is also eligible : Serving and retired regular police officers, serving and retired administration police officers, civilian in the employment of the Kenya Police Service, an employee of the Kenya Police SACCO Society, permanent employee of Utumishi Investment Limited, Permanent employee of Ruaraka Housing Estate Limited, employees of the civil service or from corporate entities operating in Kenya, the business community, spouse, son or daughter of the above members. Benefits of membership include; low-interest rates on loans, high annual dividends and interest on deposits, instant M-SACCO FOSA loans, Loan clearance on behalf of members and affordable property with the Investment Co-operative (Kenya Police SACCO, 2020).

Individual Consideration (IC)

Individual consideration is the ability of a transformational leader to recognize through observation the specific needs and desire of the employees or his followers and create for them opportunities for customized training sessions. These training activities make the team members grow and become fulfilled in their positions (Schieltz, 2019). In this study, individual consideration looked at three indicators. First, the response of individual needs and desire. A study by Ondari, Were \& Rotich
(2018) noted that in IC, transformational leaders pay special attention to each follower's needs for one's achievement and growth through the leader acting as a coach or mentor. Secondly, the process develops followers and colleagues to a successful higher level. Thirdly, individual consideration occurs when new learning opportunities are created along with a supportive climate (Ondari et al., 2018). A study by Mafini \& Pooe (2013) posits that if leaders do not meet the needs of their subjects, it causes lack of motivation and fulfilment within the employees. It can significantly affect the organization. Unsatisfied employees harm organizational performance. When people lack fulfilment in their workplaces, they develop ways to change their situation (Mafini \& Pooe, 2013). Another study by Muchiri (2017) posits that individual consideration represents experiential learning when the leader is delegating the project by providing coaching, teaching and treating each follower as an individual. Individual attention is a significant characteristic of transformational leadership. The transformational leader treats each follower as a "whole" individual rather than an employee and considers the individual's talents and levels of knowledge to decide what suits them to reach higher levels of attainment.

A study by Allen, Grigsby \& Peters (2015) examined the relationship between transformational leadership and student achievement in the United States of America (USA) in a school climate. The findings of the above research indicated that there is a significant positive relationship between individual consideration of a leader, the school climate and associated achievement. Another study in South Africa on the impact of transformational leadership on performance management: "A South African local government case study" by Isaacs (2016) confirms that transformational leadership exhibits the most preferred choice of leadership style for performance management. Transformational leadership values vision, inspiration and growth; which are essential for institutional and individual performance. In Kenya, a study carried out by Ondari, Were \& Rotich (2018) on "The effect of individual consideration on the organizational performance of state corporations" confirms that transformational leadership has a significant impact on the organizational performance of state corporations in Kenya. In another study by Tecla, Kimutia \& Kibet (2016) on the "Evaluation of the effects of transformational leadership and employee performance survey in Nandi County Government", the findings indicate a significant effect of individual consideration on employee performance. Individual consideration of employees through monetary terms seems to work best in their motivation. It involves training and mentoring them. Employees encourage each other to perform their duties (Tecla et al., 2016).

Therefore, individual consideration is the extent to which a leader attends to each follower's needs and is a mentor, coach or guide. A transformational leader listens to each follower's concerns and needs, provides support, is empathic of each person's situation and background, thus portraying respect and receiving trust in return. When a leader portrays individual consideration, they are not only aware of the unique talents that each follower brings to the workplace but also the support in developing and demonstrating these critical skills and behaviours through acting as a role model. The follower aspires to develop further. They show intrinsic motivation when performing their work, thus attaining more knowledge (Mafini \& Pooe, 2013). 


\section{THEORETICAL FRAMEWORK}

The study is anchored on three theories: Transformational Leadership Theory, Situational Leadership Theory and Maslow's Theory of needs.

According to Burkus (2010), James MacGregor Burns was the first scholar who introduced transformational leadership concepts when studying political leaders. According to Schieltz (2019), the four essential elements that underlie the theory of transformational leadership are idealized influence, inspirational motivation, ability to inspire confidence, intellectual stimulation, creativity and individual consideration of group members. In another study on the same subject, Bass (1999) notes that transformational leadership motivates the followers to perform for reasons beyond immediate self interests through idealized influence, charisma, inspiration, intellectual stimulation and individual consideration. Idealized influence and inspirational leadership are displayed when a leader envisions a desirable future, articulates how it is attainable and sets an example of achieving it through high-performance standards, determination and confidence in executing that vision. Individual consideration is displayed when the leader pays careful attention to the development of the followers.

Paul Hersey and Ken Blanchard introduced situational leadership theory, a leadership approach that matches the leader's leadership style and the followers' preparedness levels (Brandon, 2020). This leadership style works on the assumption that the most effective leadership method changes from situation to situation. A leader must adapt his style and approach to diverse circumstances to be useful and successful (OER Services, 2020). The theory identifies four main leadership approaches (Brandon, 2020). The first approach is telling, which is more of giving directives and being authoritative. In this case, the leader makes decisions and tells employees what to do. The second approach is selling, where the leader is the decision-maker but communicates and works to persuade the employees rather than merely directing them. The third approach is participation. The leader works with his team to make decisions.

Abraham Harold Maslow's Theory outlines five hierarchical needs applicable to organizations and in employees' performance (Gordon, 1965). Maslow notes that human beings do not feel the second need until the demands of the first needs are satisfied or even the third need until the second needs have been satisfied and so on. The theory has different levels of needs. These needs are physiological, safety, love, affection, belongingness, esteem and self-actualization. Maslow's theory applies to organizational cultural and human resource management roles in improving employee performance despite some criticism or limitations of the theory (Nyameh, 2013).

The three theories: Transformational Leadership Theory, Situational Leadership theory and Maslow's Hierarchy of Needs theory were found very relevant and complementary in explaining the application of independent (transformational leadership) and dependent (organizational performance) variables of the study.

Methodological Consideration

The study embraced a pragmatic philosophy, thus addressing the issues logically and practically. It employed pragmatic philosophy, quantitative and qualitative approaches and relied on the questionnaire as the tool to establish whether there was any relationship between individual consideration and organizational performance of Kenya Police, Stima and Mwalimu National SACCO Societies. Combining questionnaires and interviews in one research has the advantage of bringing together breadth and depth that are associated with qualitative and quantitative approaches. It also provides a more comprehensive picture of a research topic that can address a range of research questions. By so doing, it can provide a complete knowledge that can improve theory development and practice (Teddlie \& Tashakkori, 2009).

The research also adopted a descriptive research design. Descriptive survey design is the primary research technique investigating a problem as it exists in its current state. It identifies attributes of a specific phenomenon based on an observational basis or examining the correlation between two or more aspects (Carrie, 2007). The study therefore identified attributes and explored a relationship that may or may not exist between individual consideration and organizational performance of Kenya Police, Stima and Mwalimu National SACCO Societies.

The study narrowed down to Mwalimu National, Stima and Kenya Police Co-operative SACCO Societies. This study's sample frame included senior, middle and lower management of the three Co-operative SACCO Societies. The study's population was employees of the three Co-operative SACCO Societies including senior management and other employees of the organizations. The total number of employees of the three Co-operative societies was: Mwalimu National SACCO; 321 employees, Stima SACCO; 211 employees and Kenya Police SACCO; 121 employees hence 653 employees. The sample for this study was calculated by considering the cumulative number of employees of the three Cooperative Societies which is 653 and then applied the The Educational and Psychological Measurement by Krejcie and Morgan formula below:

$S=X^{2} \mathrm{NP}(1-\mathrm{P}) \div\left(\mathrm{d}^{2}(\mathrm{~N}-1)+\mathrm{X}^{2} \mathrm{P}(1-\mathrm{P})\right)$ (Krejcie \& Morgan, 1970).

Where,

$S=$ required sample size

$X^{2}=$ is the table value of chi-square for 1 degree of freedom at the desired confidence level and it was (3.841)

$N=$ the population size which was 653 employees

$P=$ the population proportion (which is assumed to be .50 since this provided the maximum sample size),

$d=$ the degree of accuracy expressed as a proportion (.05) (Krejcie \& Morgan, 1970).

The sample size was obtained as follows:

$\mathrm{S}=3.841 .653 .0 .50(1-0.50) /\left(0.05^{2)} .653-1\right)+3.841 \times .0 .5(1-0.5)$ $=242$ respondents.

Considering the above formula and the related computation, the sample size for the research was 242 respondents. At the end of the data collection, 193 employees responded to the questionnaire survey and 28 senior employees responded to the scheduled interview.

\section{Tabular Representation of the Sample Size}

\begin{tabular}{llll}
\hline $\begin{array}{l}\text { Profile of } \\
\text { Respondents }\end{array}$ & $\begin{array}{l}\text { Sampling } \\
\text { Technic }\end{array}$ & $\begin{array}{l}\text { Methods of data } \\
\text { collection }\end{array}$ & $\begin{array}{l}\text { Total } \\
\text { number }\end{array}$ \\
\hline 193 & Stratified & Questionnaire & \\
employees & sampling technic & survey & 193 \\
\hline
\end{tabular}




\begin{tabular}{llll}
\hline $28 \quad$ (KIs) & $\begin{array}{l}\text { Purposive } \\
\text { sampling technic }\end{array}$ & $\begin{array}{l}\text { Interview } \\
\text { schedules }\end{array}$ & 28 \\
$\begin{array}{l}\text { Senior } \\
\text { managers }\end{array}$ & & \\
Total & & \\
\end{tabular}

Source: Research (2020)

The study focused on the employees of the three Cooperative Societies with each SACCO having a sample as per the sampling technic above. The researcher then divided the population into separate groups called strata; then, a probability sample (often a simple random sample) including a total representation from each group (Trek, 2019). Employees of Stima SACCO Society formed stratum one, Mwalimu National SACCO employees' formed stratum two and the employees of Kenya Police SACCO formed stratum three. Through the use of random sampling technics, each stratum had 70 respondents.

The researcher subjectively selected a few individuals from the three SACCOs who had critical information concerning the SACCOs management to respond to interview schedules. In a homogeneous sampling study, units are selected based on having similar characteristics because they are of particular interest to the researcher. In this case, they were managers who hold key leadership positions. Qualitative or mixed methods research design used more than one type of purposive sampling technique. Homogeneous sampling used a purposive sampling technique. It aimed at achieving a homogeneous sample; that is, a sample where people or cases share the same similar characteristics or traits. In this study, the three SACCOs employees shared the same occupation. The questionnaire was specific to their features. Through a purposive sampling technique, the researcher selected 32 respondents for interviews; 11 from Stima and Mwalimu National SACCOs and 10 from Kenya police SACCO.

The target population was employees of the three SACCOs with a total population of 653 employees and a sample size of 242 respondents. The study collected data from 221 respondents (193 responded to the survey and 28 responded to interview schedules). The respondents' selection used probability and non probability sampling methods; notably through stratified and purposive sample techniques. Both primary quantitative and qualitative data was collected using a questionnaire survey and interview schedules. Secondary data was attained through the review of empirical studies.

The researcher collected primary quantitative data through a questionnaire survey while primary qualitative data was collected through interviewer schedules. The researcher collected secondary data through secondary sources through a thorough review of the literature on the same by reading books, articles and internet publications related to the topic. The structured interview schedules were open ended questions that served to the critical informants through face-to-face interviews. The interview schedules helped the researcher gain in-depth information from senior managers' experiences, views and beliefs with respect to the relationship between transformational leadership and the performance of the three selected SACCO Societies.

Quantitative data was then analyzed further through the Statistical Package for the Social Sciences (SPSS). Descriptive statistics were examined. They presented data frequencies and percentages. Through inferential statistics, the researcher established the relationship between the research variables. Pearson correlations and multivariate linear regression using the Analysis of Variance (ANOVA) model were employed to develop a causal effect relationship between the four independent and dependent variables at a 95\% level of significance. The study considered the internal consistency scores between 0.8 to 0.95 to mean that the questionnaire's internal consistency was excellent. Upon analysis of data using Lee Cronbach's alpha through SPSS, the results showed a score of 0.728 . The results indicated that the internal consistency of the questionnaire was acceptable.

\section{RESEARCH FINDINGS AND DISCUSSIONS}

Tabular Presentation of Descriptive Analysis between Individual Consideration and OP

\begin{tabular}{|c|c|c|c|c|c|c|c|}
\hline $\begin{array}{l}\text { My SACCO leaders and } \\
\text { managers observe specific } \\
\text { needs in employees and } \\
\text { create relevant } \\
\text { opportunities for them }\end{array}$ & S. Disagree & Disagree & Neutral & Agree & S. Agree & Mean & SD \\
\hline $\begin{array}{ll}\text { Mwalimu } & \text { National } \\
\text { SACCO } & \end{array}$ & $(5) 8 \%$ & (10)16\% & (23)36\% & (20)32\% & (5) $8 \%$ & 3.06 & 1.050 \\
\hline $\begin{array}{l}\text { Stima SACCO } \\
\text { Kenya Police SACCO }\end{array}$ & $\begin{array}{l}\text { (4) } 6 \% \\
\text { (1) } 1 \%\end{array}$ & $\begin{array}{l}\text { (11) } 17 \% \\
-\end{array}$ & $\begin{array}{l}\text { (28) } 42 \% \\
\text { (10) } 16 \%\end{array}$ & $\begin{array}{l}\text { (20)30\% } \\
\text { (36)56\% }\end{array}$ & $\begin{array}{l}\text { (3) } 5 \% \\
\text { (17) } 26 \%\end{array}$ & $\begin{array}{l}3.11 \\
4.06\end{array}$ & $\begin{array}{l}.947 \\
.753\end{array}$ \\
\hline $\begin{array}{l}\text { My SACCO leaders and } \\
\text { managers create trainings } \\
\text { for employees to make } \\
\text { them grow and become } \\
\text { fulfilled in their positions }\end{array}$ & & & & & & & \\
\hline $\begin{array}{l}\text { Mwalimu } \\
\text { SACCO }\end{array}$ & (2)3\% & (5) $8 \%$ & (16) $26 \%$ & (29)47\% & (10) $16 \%$ & 3.65 & .960 \\
\hline Stima SACCO & (3) $5 \%$ & (2) $3 \%$ & (6) $9 \%$ & (24)36\% & (31) $47 \%$ & 4.18 & 1.036 \\
\hline
\end{tabular}




\begin{tabular}{llllllll}
\hline $\begin{array}{l}\text { My SACCO management } \\
\text { supports coaching and } \\
\text { mentoring of skills to the } \\
\text { employees to enhance } \\
\text { personal skills }\end{array}$ & & & & & & & \\
\hline $\begin{array}{l}\text { Mwalimu National } \\
\text { SACCO }\end{array}$ & $(4) 6 \%$ & $(5) 8 \%$ & $(20) 32 \%$ & $(23) 36 \%$ & $(11) 18 \%$ & 3.51 & 1.056 \\
$\begin{array}{l}\text { Stima SACCO } \\
\text { Kenya Police SACCO }\end{array}$ & $(3) 5 \%$ & $(8) 12 \%$ & $(15) 23 \%$ & $(32) 48 \%$ & $(8) 12 \%$ & 3.52 & 1.011 \\
\hline $\begin{array}{l}\text { My SACCO employees are } \\
\text { motivated }\end{array}$ & & $(1) 2 \%$ & $(4) 6 \%$ & $(34) 53 \%$ & $(24) 37 \%$ & 4.23 & .771 \\
\hline $\begin{array}{l}\text { Mwalimu } \\
\text { SACCO National }\end{array}$ & $(3) 5 \%$ & $(9) 15 \%$ & $(20) 33 \%$ & $(24) 39 \%$ & $(5) 8 \%$ & 3.31 & .992 \\
$\begin{array}{l}\text { Stima SACCO } \\
\text { Kenya Police SACCO }\end{array}$ & $(2) 3 \%$ & $(7) 11 \%$ & $(19) 29 \%$ & $(35) 54 \%$ & $(2) 3 \%$ & 3.43 & .847 \\
\hline $\begin{array}{l}\text { My SACCO leaders and } \\
\text { manager listen and follow } \\
\text { the perception of their } \\
\text { employees }\end{array}$ & & $(1) 1 \%$ & $(3) 5 \%$ & $(25) 39 \%$ & $(34) 53 \%$ & 4.41 & .791 \\
\hline $\begin{array}{l}\text { Mwalimu National } \\
\text { SACCO }\end{array}$ & $(2) 4 \%$ & $(8) 13 \%$ & $(27) 44 \%$ & $(22) 36 \%$ & $(2) 3 \%$ & 3.23 & .844 \\
$\begin{array}{l}\text { Stima SACCO } \\
\text { Kenya Police SACCO }\end{array}$ & $(1) 2 \%$ & $(11) 17 \%$ & $(26) 40 \%$ & $(24) 37 \%$ & $(3) 4 \%$ & 3.26 & .853 \\
\hline
\end{tabular}

Leaders and Managers' Response to Specific Needs in Employees and Creation of Relevant Opportunities for Them

Transformational leaders understand and respond to the specific needs of their employees and create relevant opportunities for them. The research sought to know whether this is the case for the three SACCOs under consideration.

A simple majority of $40 \%$ of Mwalimu National SACCO respondents with $32 \%$ strongly and $8 \%$ simply agreed that their manager and leaders respond to their employees' needs and create relevant opportunities for them. These findings were against $36 \%$ of reserved and $24 \%$ respondents who disagreed, with $8 \%$ strongly and $16 \%$ simply disagreeing, attaining a mean score of 3.06 and an SD of 1.050 .

The findings present the same trend in regards to Stima SACCO. A simple majority of $35 \%$ of respondents agree to the statement with $30 \%$ strongly and $5 \%$ simply agreeing. The findings were against $42 \%$ who were reserved and $23 \%$ who disagreed, with $6 \%$ strongly and $17 \%$ simply disagreeing with the statement, attaining a mean score of 3.11 and an SD of 0.947. They are different as far as Kenya Police SACCO is concerned. An overwhelming majority of $82 \%$ of respondents indicated that their leaders and managers respond to their needs; $52 \%$ strongly and $26 \%$ simply agreeing to the statement. These were against $16 \%$ who were reserved and $1 \%$ who strongly disagreed with the statement, attaining a mean score of 4.06 and a Standard Deviation (SD) of 0.753 . Despite the fact that there was a simple majority of respondents who agreed to the statement, there was a worrying trend of another considerable percentage of respondents who were reserved and disagreed. When summed up, the two come to a cumulative rate of $60 \%$ of the respondents. However, the research would infer that leaders and managers of Mwalimu National SACCO consider and respond to employees' needs and create opportunities for them. The study would also infer the same for
Stima SACCO and obviously for Kenya Police SACCO. Furthermore, analysis of means and SD score revealed that Kenya Police SACCO leads in terms of considering and responding to employees' needs for having scored more in average (Means=4.06) and being more consistent $(\mathrm{SD}=0.753)$ followed by Stima SACCO $($ Mean=3.11) and $(\mathrm{SD}=0.947)$ and Mwalimu National SACCO $($ Mean=3.06) and $(\mathrm{SD}=1.050)$.

The views of Key Informants (KIs) on the topic were as follows; when asked whether he is satisfied that his needs are responded to, Mwalimu Key Informant (MKI1) responded that, "Yes, I do, and I also accommodate them when they cannot respond; maybe they are also caught up with Board issues" (MKI1, 22/06/2020).

MKI2 indicated that he is satisfied with the management and leadership of the SACCO response to his needs and desires. He further noted that support has been there in terms of resources and ideas, appreciating what one is doing. According to him, it "gives him courage in reaching out to the level of the senior manager" (MKI2, 22/06/2020).

Analysis of KIs responses to the question indicates that leaders and managers of Mwalimu National SACCO consider and respond to employees' needs and create opportunities for them, which positively impacts the performance of the SACCO. Correlational analysis also confirmed that the variable is significant for SACCO performance. While acknowledging the same, other MKIs admitted that there is still room for improvement regarding and responding to employees' needs and creating opportunities for them.

The following are views of KIs from Stima SACCO as far as this variable is concerned. According to Stima Key Informant (SKI1), "I would say that I have never had such an employer when it comes to employees' welfare. When it comes to pension, allowances, leave, insurance for medical, they have tried. They have done their best', (SKI1, 17/06/2020). 


\section{According to SKI3...}

"...we have training systems that provide four to five training per year per staff. Now we have been given a budget that caters for 150 training seminars in total. One can attend any seminar of choice provided that the training is within the budget. The second point is that remuneration is ok, according to the industry. The rate of turnover is meagre", (SKI3, 17/06/2020).

Without repeating the responses by other SKIs, the research would infer that SKIs acknowledge that the leadership and management of Stima SACCO recognizes and responds to employees' needs and creates opportunities for them. The correlational analysis does not show any significance between the two variables. However, it showed a positive correlation between the two variables as confirmed by quantitative and qualitative data. Therefore, Stima SACCO leadership and management ideally considers the needs of employees significantly influencing the organization's performance. Barett (2014) confirms the same and notes, "when employees' needs are met, and employees feel aligned with the organization's mission, vision, and values, they each respond positively with engagement and commitment; report to work with a lot of enthusiasm and are willing to go the extra mile to support the organization in its endeavours".

The following are the views of Kenya Police SACCO KIs (PKIs). It is worth reminding that the overwhelming majority of respondents of Kenya Police SACCO agreed to the fact that the leadership and management of the society considers and responds to the needs of employees and creates opportunities for them. The view of the PKIs was as follows:

According to PKI2, Kenya Police SACCO's management and leadership endeavours to provide a conducive working environment for its staff and members. They have training programs, capacity building sessions and recognition programs that keep them motivated. As member needs arise, they have a formal way of handling them, notably through mid and end year appraisal programs. However, some of the needs are attended to on the spot (PKI2, 19/06/2020).

Responses from Kenya Police SACCO informants were not different from those captured from the other two SACCOs, still acknowledging and indicating that the SACCO managers and leaders recognize and respond to the staff's needs and create opportunities for them.

In summary, both quantitative and qualitative data concur that the managers and leaders of the three SACCOs recognize and respond to employees' needs and create opportunities for them. Although this has been confirmed by an overwhelming majority in Kenya Police SACCO and by a simple majority in Mwalimu National and Stima SACCOs, the study would conclude that by responding to the staff needs and creating opportunities for them, the managers and leaders ideally consider employees individually and collectively as far as their performance is concerned.

Provision of trainings for employees to make them grow and become fulfilled in their positions

A transformational leader or manager creates an opportunity for training to grow and become fulfilled in their positions. The process is an element of idealized consideration of employees that positively influences the performance. In seeking to establish whether there is any relationship between idealized consideration and OP, the research sought to know whether leaders and managers of the three SACCOs create training opportunities for their employees. The findings are as per table 1. According to the study, majority of $63 \%$ of respondents at Mwalimu National SACCO strongly (47\%) and simply (16\%) agreed that managers and leaders of the SACCO create trainings for employees to make them grow and become fulfilled; against $26 \%$ who were reserved and $11 \%$ who strongly (3\%) and (8\%) who simply disagreed with the statement with a mean score of 3.65 and SD of 0.960 .

As far as Stima SACCO was concerned, there was overwhelming majority (83\%) who strongly (36\%) and simply (47\%) agreed to the statement against 9\% who were reserved while $8 \%$ strongly $(5 \%)$ and simply $(3 \%)$ with a mean score of 4.18 and SD of 1.036 .

An overwhelming majority (94\%) of Kenya Police SACCO respondents strongly (31\%) and simply (63\%) agreed to the statement while $1 \%$ was reserved and $5 \%$ strongly $(2 \%)$ and simply (3\%) disagreed to the statement with a mean score of 4.16 and SD of 0.816 .

According to these findings, the research concludes that the three SACCO leaders create opportunities for training for employees that help them grow and be fulfilled in their careers. Stima SACCO leads in terms of scoring more on an average of (Mean=4.18), followed by Kenya Police SACCO $($ Mean= 4.16) and Mwalimu National SACCO (Mean=3.65). As far as consistency is concerned, Kenya Police SACCO leads with an SD of 0.816, followed by Mwalimu National SACCO (0.960) and Stima SACCO (1.036) with respect to creating training for employees.

The research would infer that the three SACCOs leaders and managers under consideration uphold one crucial element of idealized consideration: the provision of training to ensure that their staffs are grown and fulfilled in their career path. The views of KIs do not differ from these quantitative data. From one SACCO to another, all of them acknowledge the provision of training for staff. One common practice to the three SACCOs is providing a budget whereby the best employee of the year attends international training abroad. The following are views from the KIs of Mwalimu National SACCO.

The research would conclude that the three SACCOs leaders and management ideally consider every employee and offer them training to grow and become fulfilled in their respective positive since the three analyses concur without contradiction. The findings have a positive and significant impact on the performance of the three societies.

Support of Coaching and Mentoring Employees' Skills to Enhance Personal Skills

Coaching and mentorship are considered elements of idealized consideration that transformational leaders ought to foster for organization performance. In seeking to understand the relationship between TL and OP, the research also sought to establish whether managers and leaders of the three SACCOs consider coaching and mentoring their employees.

A simple majority $(54 \%)$ of respondents at Mwalimu National SACCO strongly (36\%) and simply (18\%) agreed to the statement, $32 \%$ were reserved while $14 \%$ strongly $(6 \%)$ and simply (8\%) disagreed, with a mean score of 3.51 and SD score of 1.056 . 
With focus on Stima SACCO, a majority of $60 \%$ strongly (48\%) and simply (12\%) agreed to the statement, $23 \%$ were reserved while $17 \%$ strongly (5\%) and simply (12\%) disagreed to the statement, with a mean score of 3.52 and an SD score of 1.011. In reference to Kenya Police SACCO, once again the findings show an overwhelming majority of respondents (90\%) who strongly (53\%) and simply (37\%) agreed to the statement, 6\% were reserved while $4 \%$ strongly (2\%) and simply (2\%) disagreed, with a mean score of 4.23 and an SD of 0.771 .

In consideration of the majority of respondents under each SACCO who agreed to the statement, the analysis of this data would infer that the management and leadership of these three SACCOs coach and mentor their employees to enhance personal skills with Kenya Police SACCO taking the lead in terms of scoring more on average (Mean $=4.23$ ) and in consistency $(\mathrm{SD} .=$ 0.771 ) as far as coaching and mentorship are concerned, followed by Stima SACCO (Mean $=3.52 ; \mathrm{SD}=1.011)$ and Mwalimu National SACCO $($ Mean=3.51; SD.=1.056).

As far as qualitative data was concerned, the view of the KIs concurred on the fact that the three SACCOs do not have any coaching and mentorship policy in place. The process is left to the discretion of the department managers. Coaching was covered under trainings as a way of enhancing employee's skills towards better performance.

Like the case for Mwalimu National and Stima SACCO, coaching and mentorship of staff are still considered a business practice that is left the discretion of the head of department to improve the performance of the staff and organization and ensure leadership succession. Both quantitative and qualitative data concurred and confirmed that the leadership and management of the three SACCOs coach and mentor their personnel. The study sought to establish any correlation between the variable and OP of the three SACCOs.

The two analyses confirm that the leadership and management of the three SACCOs coach and mentor their employees. The practice is considered key to the performance of the society and organization succession. There is no policy guide on coaching and mentorship of employees in the three SACCOs. They are considered a business practice left to the discretion of the department manager. Everybody agrees on the importance of coaching and mentoring staff. The leadership and management of the three SACCOs have understood that mentorship/coaching helps build a positive and concrete change in individuals and boost the transfer of knowledge from the coach/mentor to the individual as they are profoundly beneficial for the career growth of their employees. The purpose is to strengthen employees' skills, working behaviour lapses and problems with performance output and improve their potential to achieve better in and through employees' jobs by being more prolific (Phrenimos, 2020). In consideration of the research results and borrowing from Ray (2020), the leadership and managers of the three SACCOs "understand the value of prioritizing their time in order build a personal connection with each team member, regardless of their title, tenure or job description."

Employees Motivation

Motivation is critical to performance. Acknowledging the good work of employees contributes to better performance. A transformational leader must put in place strategies and systems to motivate his followers. The research sought to know whether this is the case for the SACCOs under consideration. Have employees ideally been individually considered in terms of work performed? Are they appreciated? Do they feel appreciated for the excellent work and commitment to achieving the SACCOs goals?

As far as Mwalimu National SACCO was concerned, a simple majority $(47 \%)$ strongly (39\%) and simply (8\%) agreed that they were motivated to work at Mwalimu National SACCO against $33 \%$ who were reserved and $20 \%$ who strongly (5\%) and simply (15\%) disagreed to the statement, with a mean score of 3.31 and an SD of 0.992.

The trend was the same for Stima SACCO whereby a simple majority (57\%) strongly (54\%) and simply (3\%) agreed against $29 \%$ who were reserved and $14 \%$ who strongly (3\%) and simply (11\%) disagreed with a mean score of 3.43 and SD of 0.847.

Kenya Police SACCO presents an overwhelming majority of $92 \%$ of respondents who strongly (39\%) and simply (53\%) agreed to the statement against $5 \%$ who were reserved and $3 \%$ who strongly $(2 \%)$ and simply (1\%) disagreed with a mean score of 4.41 and SD of 0.791 .

In any case, the findings present an overwhelming and simple majority confirming that employees of the three SACCOs are motivated, with Kenya Police SACCO showing an overwhelming percentage in regards to quantitative results. Their respective mean scores also approve the results with Kenya Police SACCO still leading with more average (Mean= 4.41) and consistency $(\mathrm{SD}=0.791)$ followed by Stima SACCO $($ Mean=3.43; S.D=0.847) and Mwalimu National SACCO (Mean=3.31; $\mathrm{SD}=0.992$ ) as far as motivating the staff is concerned.

The qualitative data findings revealed a common trend among the three SACCOs. All respondents confirmed that their respective SACCOs have incentive practices that include practices like the best employees of the year award, payment of year-end bonuses, provision of national and international seminars. They are yet to have a policy on the same. At their discretion, the managers apply other motivators to acknowledge the personnel's excellent performance under them. These include the provision of lunch and open acknowledgment of staff performance during the department meeting.

The research concludes that motivation of employees if left at the discretion of department managers who have to come up with informal and personal ways of acknowledging the work of their staff. Formal policies do not exist but business practices and motivators such best employees of the year, payment of bonus exist. They happen to be implemented only at the end of the year. In their recommendations, all KIs insisted on the need to have such policies not only at the end of the year but throughout the year. The leaders and managers of the three SACCOS consider their respective personnel through informal and formal motivation practices.

Listening and Following Up On Employees' Perception

When asked whether leaders and managers listen a follow the perception of their employees; $39 \%$ strongly, (36\%) and simply (3\%) agreed at Mwalimu National SACCO against 44\% who were reserved and $17 \%$ who strongly (4\%) and simply (4\%) disagreed with a mean score of 3.23 and SD of 0.844 .

The trend is similar with Stima SACCO whereby a simple majority of $41 \%$ strongly (37\%) and simply (4\%) agreed against $40 \%$ who were reserved, $19 \%$ who strongly (2\%) and simply $(17 \%)$ disagreed with a mean score of 3.26 and SD of 0.853 . 
Kenya Police SACCO shows a net difference in the percentage still with an overwhelming majority of $81 \%$ who strongly $(50 \%)$ and simply (31\%) agreed against $16 \%$ who were reserved and $3 \%$ who simply disagreed with a mean of 4.09 and SD score of 0.771 . The findings revealed two simple and one overwhelming majority as far as quantitative data indicates that the SACCOs listen to their employees' perception of the management. However, the ideal would have been to get the opinion of a significant number reserved and did not want to give their idea. The research offered an option but the ideal would have been to either agree or disagree with the statement.

Furthermore, the analysis of the means still confirms Kenya Police SACCO on the lead with scoring more on average $($ Mean=4.09) followed by Stima SACCO (Mean=3.36) and Mwalimu National SACCO (Mean=3.23) as far as listening to the staff perceptions is concerned.

Analysis of SD scores put Kenya Police SACCO on the lead for being more consistent $(\mathrm{SD}=0.771)$, followed by Mwalimu National SACCO $(\mathrm{SD}=0.844)$ and Stima SACCO $(\mathrm{SD}=0.853)$ respectively regarding the same. Kenya Police SACCO is the best in terms of motivating its staff towards achieving better performance.

The analysis of the means still confirms Kenya Police SACCO on the lead scoring more on average (Mean=4.09) followed by Stima SACCO (Mean=3.36) and Mwalimu National SACCO $($ Mean=3.23) as far as listening to the staff perceptions is concerned. Analysis of SD scores put Kenya Police SACCO on the lead for being more consistent $(\mathrm{SD}=0.771)$ followed by Mwalimu National SACCO (SD=0.844) and Stima SACCO $(\mathrm{SD}=0.853)$ respectively regarding the same. Kenya Police SACCO is the best in terms of motivating its staff towards achieving better performance.

The research understands that the three SACCOs have not put any formal way of getting to understand the perception of employees across them. It is left to managers' and leaders' discretion to understand those perceptions and address them towards better performance. The process is understood to be critical and significant not only for employees' performance but also for the societies' performance.

Talview (2016) argues on the same and notes that in employee relations, perception is a significant factor. It is formed by organizational roles, leadership styles and communication styles at the workplace amongst many others. The organization must be able to create the correct perception in the minds of its employees. Thus, proper and effective supervision is required to prevent employees from having a wrong understanding. An organization will always thrive if its employees are happy and satisfied. Being conscious of your brand perception and putting effort into maintaining it will not just help your organization today but lay the foundation of trustworthy work culture for years to come.

In summary, the two analyses confirmed that managers and leaders of the three SACCOs make use of individual consideration indicators either formally or informally.

The objective of the study sought to establish whether there is any relationship between idealized consideration and OP of the three SACCOs under consideration. Staff motivation, review of staff perception, needs, opportunities and needs for training to make the employees fulfilled in their careers, coaching and mentorship of employees were considered elements of idealized consideration under TL. The findings involved four analyses: analysis of quantitative data and qualitative data, correlational and regression analysis. The four analyses confirmed that managers and leaders of the SACCOs make use of these practices either formally or informally.

The findings also confirmed that these variables have positive correlations with the Dependent Variable (DV), which is OP. Regression analysis also demonstrated a significant relationship between the two variables, leading to the rejection of the second null hypothesis. Thus, the researcher concluded that there is a significant relationship between idealized consideration and OP of the three SACCOs.

The findings also revealed that while there are no formal policies or the policies are in the process of being formulated, most of the business practices under idealized consideration are at the discretion of managers and leaders. As far as the ranking of the SACCOs is concerned, Kenya Police SACCO continues to take the lead by scoring more on average and inconsistencies as far as respective variables are considered. From a theoretical perspective, the research confirmed the application of transformational and situational theories of leadership. Transformational theory is justified by using idealized consideration elements. Situational leadership theory is found applicable as a result of leaders and managers applying different business practices to respond to diverse situations of needs, perceptions, challenges and motivation of employees.

While the study shows a significant relationship between the two variables, findings of a study by Ngaithe \& Ndwiga (2016) are not consistent with the study. The study indicated that the results for the effect of individualized consideration on organization performance show that the coefficient for individualized consideration was -2.487 with a p-value of 0.09 . The significant $\mathrm{p}$-value at $10 \%$ level implies that individualized consideration negatively influences organizational performance. The findings rejected the null hypothesis and concluded that individualized consideration does not affect organizational performance of commercial SOEs in Kenya.

Correlation Analysis between Indicators of Individual Consideration and OP

Pearson correlation analysis was carried out between the eight elements of idealized influence and organization performance of the three SACCOs under consideration.

Correlations between Observation of Employees' Needs and

OP

The findings for Mwalimu National SACCO at $11 \%$ were $(\mathrm{r}=0.402 ; \mathrm{n}=63 ; \mathrm{p}=0.001<0.01)$ with significance at level 0.01 . It is important to note that the findings indicate that Mwalimu National SACCO leaders and managers respond to the needs and create opportunities for employees are considered factors that positively influence the Mwalimu National SACCO performance. The correctional analysis supports findings from quantitative data. All the three correlational analysis reveal positive correlation between the two variables at $29 \%(r=0.293 ; n=62 ; \mathrm{p}=0.021<0.05)$ for Mwalimu National SACCO; 25\% (r=0.257; $\mathrm{n}=66$, $\mathrm{p}=0.037<0.05)$ for Stima SACCO and $37 \%(\mathrm{r}=0.376 ; \mathrm{n}=64 ; \mathrm{p}=$ $0.002<0.05$ ) for Kenya Police SACCO, with significance at level 0.05 in regards to the three cases under consideration. The findings 
mean that training employees is positive and significant to the performance of the three SACCOs.

The research would infer that since the three analyses concur without contradiction, the three SACCOs leaders and management ideally consider every employee and offer them training to grow and become fulfilled in their respective position, which positively and significantly impacts the performance of the societies.

\section{Correlations between Coaching/Mentorship and OP}

Correlational analysis shows a positive correlation between the variables in regards to the three SACCOs at level $40 \%$ $(\mathrm{r}=0.403 ; \mathrm{n}=63), \mathrm{p}=0.006<0.01)$ for Mwalimu National SACCO, a weak positive correlation $23 \%(\mathrm{r}=0.232 ; \mathrm{n}=66 ; \mathrm{p}=0.06>0.01)$ for Stima SACCO and also a weak but positive correlation at $34 \%$ $(r=0.342 ; n=64 ; p=0.006<0.01)$ for Kenya Police SACCO. The correlation is significant only regarding Mwalimu National SACCO and Kenya Police SACCO only at level 0.01. The positive correlation is without significance for Stima SACCO at level 0.01. The findings indicate that while coaching and mentoring staff is significant to Kenya Police and Mwalimu SACCOs performance, this is not the case for Stima SACCO even though it positively affects the same performance.

\section{Correlations between Motivation of Staff and OP}

Findings from correlational analysis revealed that positive correlations across the three SACCOs at 47\% $(r=0.476 ; n=61 ; p=$ $0.000<0.01)$, ) for Mwalimu National SACCO; 35\% $(\mathrm{r}=0.355$; $\mathrm{n}=65 ; \mathrm{p}=0.004<0.01)$ for Stima SACCO and $47 \%(\mathrm{r}=0.478 ; \mathrm{n}=64$; $\mathrm{p}=0.000<0.01$ ) for Kenya Police SACCO. Furthermore, the same analysis indicates that the positive correlations are significant for the three SACCOs at level 0.01. The results mean that motivating the staff is important and significant to their performance and to the three SACCOs performance. The findings are further confirmed by Samiksha (2020) when she noted that motivation induces people to behave in such a manner to achieve their goals. Since it is a psychological phenomenon, motivation responds to employees' internal feelings such as need, desire and aspirations among other factors. It influences their human behavior to behave in a particular manner.

Correlations between Listening Perceptions of Employees and OP Findings revealed positive correlations between the two variables at $36 \%(\mathrm{r}=0.364 ; \mathrm{n}=61, \mathrm{p}=0.004<0.01)$ for Mwalimu National SACCO, 21\% $(r=0.217 ; n=65 ; \mathrm{p}=0.083>0.01)$ for Stima SACCO and $43 \%(r=0.438 ; n=64 ; \mathrm{p}=0.000<0.01)$ for Kenya Police SACCO. Furthermore, the correlations are positive and significant only for Mwalimu National and Kenya Police SACCOs at level 0.01 while it is not significant for Stima SACCO still at level 0.01. This means that listening and responding to the perception of employees is key and significant for their performance and the performance of the organization for Mwalimu National and Kenya Police SACCOs. The same is important for Stima SACCO with no significance.

In conclusion, correlational analysis carried out between indicators of individual consideration and OP revealed a positive and sometimes weak correlation between the indicators of individual consideration and the DV. The findings indicate that when these indicators are upheld by the management and leadership of the three SACCOs, they positively contribute to the SACCOs performance. Individual consideration is positively related to organizational performance of the three SACCOs with some elements being significant while others not being significant to the same. The findings are consistent with a similar study in the coastal region of Kenya where a correlational analysis between these two variables also confirmed a positive relationship. According to the study findings, the results indicate that there was a positive relationship $(r=0.164)$ between individual consideration and organizational performance of steel manufacturing companies in the coastal region. In addition, the researcher found the relationship to be statistically significant at $5 \%$ level $(\mathrm{p}=0.0223<0.05)$ (Maina \& Gichinga, 2018). However, a similar study by Ndwiga \& Ngaithe (2016) on "The effect of individual consideration and intellectual stimulation on organizational performance of commercial state owned enterprises in Kenya", individual consideration negatively influences organizational performance.

\section{REGRESSION ANALYSIS}

Inferential statistics such as non parametric tests including ANOVA tested the overall model's significance at a 95\% (0.05) level of significance. The null hypothesis is rejected when the Pvalue is inferior to the significance level $(\mathrm{p}<0.05)$. According to the study's null hypothesis, there is no significant influence between individual consideration and OP of the three SACCOs under consideration. The following formula was used:

$\mathrm{Ys}=\beta_{0}+\beta_{1} \mathrm{X} 1+\varepsilon \mathrm{i}$

Whereas;

Ys = Organizational Performance

$\mathrm{X}_{2}=$ Individual Consideration

$\beta_{0}=$ Constant (coefficient of intercept)

$\varepsilon=$ Error term 
Tabular Representation of Null Hypothesis Testing

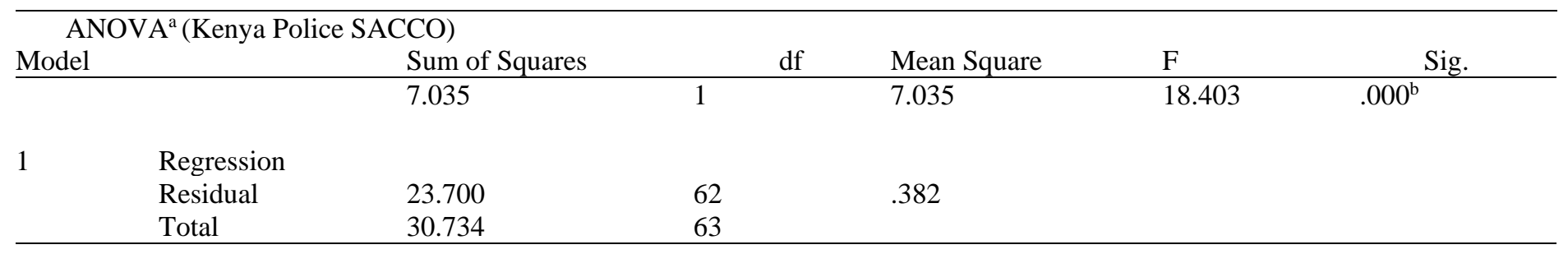

ANOVA $^{\mathrm{a}}$ (Mwalimu National SACCO)

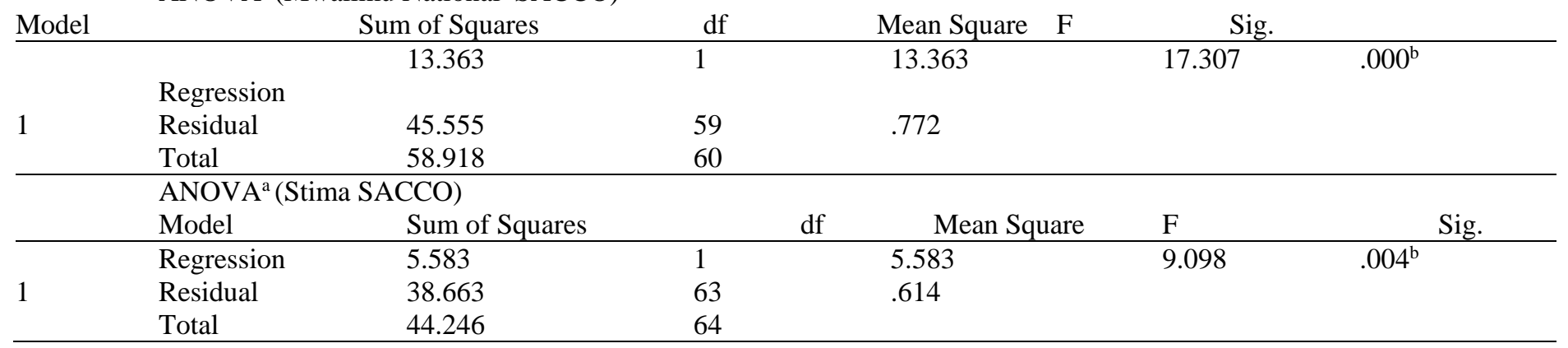

a. Dependent Variable: I am satisfied with the performance of my SACCO

b. Predictors: (Constant), My SACCO employees are motivated

Using motivation as key element of idealized consideration, findings from regression analysis revealed that the significance values for Kenya Police SACCO (Sign. $=0.000)$, Stima SACCO $($ Sign. $=0.000)$ and Mwalimu National SACCO $($ Sign. $=0.004)$ are less than the P-value (0.05). This means that the research rejects the null hypothesis and concludes that there is a significant relationship between individual consideration and OP of Mwalimu National, Stima and Kenya Police SACCOs. The findings are also consistent with another study on the influence of individual consideration on employee job performance in the insurance industry in Kenya by Langat, Linge \& Sikalieh (2019). Findings revealed that ANOVA for individual consideration and employee job performance was significant. The findings implied that the overall model was statistically significant in determining the relationship between idealized influence and employee job performance among lower level managers in insurance companies in Kenya.

From the above findings, staff motivation, review of staff perception, needs, opportunities and needs for training to make the employees fulfilled in their careers, coaching and mentorship of employees were considered indicators of individual consideration under TL. The findings involved four analyses: analysis of quantitative and qualitative data, correlational and regression analysis. The four analyses confirmed that managers and leaders of the SACCOs make use of these practices either formally or informally. The findings also confirmed that these variables have positive correlations with the DV, which is OP. Regression analysis also demonstrated a significant relationship between the two variables, leading to the rejection of the null hypothesis. Thus, the researcher concluded that there is a significant relationship between individual consideration and OP of the three SACCOs. Furthermore, it is worth mentioning that some indicators of individual consideration require personality focus, employees were free to give subjective views, which might be disputed by the concerned. Managers acknowledged that they found it difficult to respond to some of the questions that should be answered by other people. The research also noticed considerable percentages of respondents who were rather reserved, especially in regards to Stima and Mwalimu National SACCOs. These are areas that the managers of the two SACCOs should consider for improvement as far as the management is concerned. As far as the management ranking and as confirmed by findings under individual consideration, Kenya Police SACCO ranks first in terms of using indicators of individual consideration with overwhelming percentages of respondents who confirmed the same.

The research also revealed that while there are no formal policies or the policies are in the process of being formulated, most of the business practices under individual consideration are at the discretion of managers and leaders. As far as the SACCO ranking is concerned, Kenya Police SACCO continues to take the lead by scoring more on average and inconsistencies as far as respective variables are considered. From a theoretical perspective, the research confirmed the application of transformational and situational theories of leadership. While the transformational theory is justified by using individual consideration elements, situational leadership theory is found applicable due to leaders and managers applying different business practices to respond to diverse situations of needs, perceptions, challenges and employees' motivation. While many studies, including this one, confirm a significant relationship between the two variables; Ngaithe \& Ndwiga (2016) findings are not consistent with the study. The results show that the coefficient for individual consideration was -2.487 with a P-value of 0.09 . The significant P-value (at $10 \%$ level) implies that individual consideration has no influence on organizational performance. 


\section{CONCLUSION}

Employees are satisfied with the performance of their respective SACCOs. This performance is attributable to several factors including market share, which results from standing the test of time and national coverage. Furthermore, another essential element that is contributing to their performance is the leadership style that is applied. There is no one specific leadership style applicable. The application of one leadership style depends on the situation and needs at hand.

With a focus on TL, the study confirmed that individual consideration was found to have a significant relationship with $\mathrm{OP}$ of the three SACCOs.

The finding confirms much other literature on the same and the view that TL has considerable attention because of its potential implications on an organization's performance.

The research findings, especially qualitative ones, indicate that individual consideration is being applied formally and informally. The results also confirmed that the three SACCOs have some policy on enhancing employees' capacity through different training which need to be improved. It should be incorporated into the appraisal framework for better implementation and evaluation. Therefore, the research joined many other empirical studies and confirmed the significance of individual consideration to OP of SACCOs.

\section{RECOMMENDATIONS}

From the results of this study, the following recommendations are made to various stakeholders in the industries:

To the SACCO Society Regulatory Authority

Considering TL's significance on the OP of SACCOs following this research, the study recommends that every SACCO should fully and formally have principles of individual consideration in place and enhance their application. The elements of individual consideration should be compulsory and regulated for any SACCO leadership and management. A policy framework should be put in place for adoption and full implementation.

To Managers and Leaders of Mwalimu National, Stima and Kenya Police SACCOs

The managers, leaders and management of every SACCO should embrace the following:

To consider taking advantage of these principles of individual consideration and facilitating their smooth implementation by adopting policies that would regulate their performance.

Consider incorporating principles individual consideration in regular appraisals and provide necessary responses to the staff beyond what is provided in existing policies.

\section{REFERENCES}

[1] Ahmed, M., Alaa, M. \& Asmaa, K. (2014). Relationship between Transformational Leadership and Balanced Scorecard in South Valley University. International Journal of Business Management and Economic Research (IJBMER), Vol 5(6), 104 - 110.

[2] Allen, N., Grigsby, B. \& Peters, M. (2015). Does leadership matter? Examining the Relationship Does leadership matter? Examining the Relationship and Student Achievement. NCPEA International Journal of Educational Leadership Preparation, Vol. 10, No. 2, 1 - 22Bass \& Bass
(2008). The Bass handbook of leadership: Theory, research, and managerial applications (4th ed.). New York: Free Press.

[3] Barrett, D. (2014, September 2). Understanding Employee Needs: Key to Creating a Highly Motivated Workforce. Retrieved from Talent Management \& HR: https://www.tlnt.com/understanding-employee-needs-key-tocreating-a-highly-motivated-workforce/

[4] Bass \& Bass (2008). The Bass handbook of leadership: Theory, research, and managerial applications (4th Ed.). New York: Free Press.

[5] Bass, B. (1999). Two decades of research and development in transformational leadership. European Journal of Work and Organizational Psychology, 8(1), 9 - 32.

[6] Bilginoğlu, E., Uğur Y. \& Erdem A. (2019). Respect and Trust in Organizations: A Research About Their Effect on Job Satisfaction. International Journal of Society Researchers, vol.12, 9. 529 - 543.

[7] Brandon, G. (2020, January 3). Situational Leadership Advantages and Disadvantages. Retrieved from Small Business and Marketing advice: https://brandongaille.com/13-situational-leadership-advantages-anddisadvantages/.

[8] Burkus, D. (2010, March 18). What Is Transformational Leadership Theory? Retrieved from Transformational Leadership Theory: https://davidburkus.com/2010/03/transformational-leadership-theory/

[9] Eeden, (R) Cilliers, (F), \& Deventer, (V), (2008).Leadership Styles and Associated Personality Traits: Support for the Conceptualisation of Transactional and Transformational Leadership, June 2008, South African Journal of Psychology 38(2):253-267.

[10] Eeden, (R) Cilliers, (F), \& Deventer, (V), (2008).Leadership Styles and Associated Personality Traits: Support for the Conceptualisation of Transactional and Transformational Leadership, June 2008, South African Journal of Psychology 38(2):253-267.

[11] Gordon, G. (1965). The relationship of satisfiers and dissatisfiers to productivity, turnover and morale . American Psychologist, 20, 499-502.

[12] Grossman, D. (2019, May 06). Trust in the Workplace: 6 Steps to Building Trust with Employees. Retrieved from LeaderCommunicator: https://www.yourthoughtpartner.com/blog/bid/59619/leaders-follow-these6-steps-to-build-trust-with-employees-improve-how-you-re-perceived.

[13] Isaacs, J. (2016). The Impact of Transformational Leadership on Performance Management: A South African Local Government Case Study. Stellenbosch: Stellenbosch University.

[14] Khanna, T. (2018). Trust as the Foundation of Finance. The Journal of Indian Institute of Banking \& Finance, 27 - 34.

[15] Kulei, S., Kipkirui, W. \& Kipkorir, L . (2019). Effect of inspirational motivation and idealized influence on employee performance at Moi Teaching and Referral Hospital, Edoret, Kenya. International Journal of Business and Social Science, Vol. 10 - No. 7, 131 - 140.

[16] Langat, G., Linge, T. \& Sikalieh, D. (2019). nfluence of idealized influence on employee job performance in the insurance industry in Kenya. International Journal of Research in Business and social science 8(5), 266273.

[17] Liu, D., Liao, H. \& Loi, R. (2012). The dark side of leadership: A three-level investigation of the cascading effect of abusive supervision on employee creativity. Academy of Management Journal, 55, 1187-1212.

[18] Louise, J. (2012, September 10). What is Organisational performance? Retrieved from Pitcher Partners Growth: http://www.growth.pitcher.com.au/resources/articles/what-isorganisational-performance.

[19] Mafini, C. \& Pooe, D. (2013). The relationship between employee satisfaction and organisational performance: Evidence from a South African government department. SA Journal of Industrial Psychology, 39(1), 1 - 9.

[20] Maina, A. \& Gichinga, L. (2018). The effect of transformational leadership on organisation performance of Steel Manufacturing compagnies in Coast region, Kenya. The Strategic Journal of Business \& Change Management, Vol. 5, Iss. 4,, 1487 - 1508.

[21] Maina, A. \& Gichinga, L. (2018). The effect of transformational leadership on organisation performance of Steel Manufacturing companies in Coast region, Kenya. The Strategic Journal of Business \& Change Management, Vol. 5, Iss. 4, 1487 - 1508.

[22] McGuire, E. \& Kennerly S. (2006). Nurse Managers as transformational and transactional leaders. Nursing Economics 24 (4), 179-185.

This publication is licensed under Creative Commons Attribution CC BY 
[24] Muchiri, C. (2017). Influence of Transformational leadership on organisational perforance of commercial banks of Kenya. Nairobi: Jomo Kenyatta Univrity of Agriculure and Technology.

[25] Murage, S., K'Aol, G. \& Njenga, K. (2017). Effect of Idealized influence and Inspirational motivation of the CEO on the Performance in the Private Sector in Kenya. American Journal of Leadership and Governance Vol.1, Issue 2, No. 2, 16 - 38 .

[26] Mwaka, J. (2019). The SACCO supervision report Annual Report, 2018. Nairobi: The SACCO Societies Regulatory Authority.

[27] Mwaka, J. (2019). The SACCO supervision report Annual Report, 2018. Nairobi: The SACCO Societies Regulatory Authority.

[28] Ndwiga, M. \& Ngaithe, L. . (2016). The Effect of Individualized Consideration and Intellectual Stimulation on Organizational Performance of Commercial State Owned Enterprises in Kenya. Journal of Economics and Sustainable Development Vol.7, No.20,, 14 - 21.

[29] Nyameh, J. (2013). Application of the Maslow's hierarchy of need theory; impacts and implications on organizational culture, human resource and employee's performance. International Journal of Business and Management Invention, Volume 2 Issue 3, 39-45.

[30] OER Services. (2020, January 3). Situational Theories of Leadership. Retrieved from Principles of Management: https://courses.lumenlearning.com/sunyprinciplesmanagement/chapter/situational-theories-of-leadership/.

[31] Ojokuku, R., Odetayo, T. \& Sajuyigbe, A. (2012). Impact of leadership style on organisational performance: a case study of Nigeria Banks. American Journal of Business and Management, 1(4), 202 - 207.

[32] Ondari, W. (2018). Effect of Individualized consideration on organisational performance of State Corporations in Kenya. The Strategic Business \& Changement Journal of Management, Vol. 5, Issue 1, 210 - 246.

[33] Orabi, A. (2016). The Impact of Transformational Leadership Style on Organizational Performance:. International Journal of Human Resource Studies 6(2)., 89 - 102.

[34] Page, L., Boysen, S. \& Arya, T. (2019). Creating a culture that thrives: fostering respect, trust, and psychological safety in the workplace. Organization Development Review, 51(1), 28-35

[35] Ray, M. (2020, April 29). Transformational Leadership: Idealized Influence. Retrieved from MichelleRay: https://www.michelleray.com/transformational-leadership-idealizedinfluence/.

[36] Raza, A. (2019, February 20). 12 Different Types of Leadership Styles. Retrieved from Leadership: https://wisetoast.com/12-different-types-of- leadership-styles/. Retrieved from Leader Communicator : https://www.yourthoughtpartner.com/blog/bid/59619/leaders-follow-these6-steps-to- build-trust-with-employees-improve-how-you-re-perceived.

[37] Samiksha, S. (2020, September 23). Importance of Motivation for Employees. $\quad$ Retrieved from $\quad$ Your articlelibrary: https://www.yourarticlelibrary.com/employee-management/importance-ofmotivation-for-employees-employee-management/8681.

[38] Schieltz, M. (2019, February 4). Four Elements of Transformational Leadership. Retrieved from Chron: https://smallbusiness.chron.com/fourelements-transformational-leadership-10115.html.

[39] Tecla, J., Kimutia, G., and Kibet , Y. . (2016). Evaluation Of Effects of Transformational Leadership and Employee Performance a Survey of Nandi County Government. IOSR Journal of Business and Management (IOSRJBM) Volume 18, Issue 11. Ver. I, 91-101.

\section{AUTHORS}

First Author: Jossylyn Nzilani Mutua is a student at Pan African Christian University. She can be contacted at nzilamutua@gmail.com.

Second Author: Dr. Theresia Mueni Mutetei is a Research Associate and Adjunct Lecturer, Pan African Christian University. Her email address is:

theresia.mutetei@ pacuniversity.ac.ke

ThirdAuthor: Dr. Cavens Kithinji is a Registrar; Administration and Planning, Lecturer Community Development, Pan African Christian University. His email address is: cavens.kithinji@ pacuniversity.ac.ke

Correspondence Author: Jossylyn Nzilani Mutua is a student at Pan African Christian University. She can be contacted at nzilamutua@gmail.com or Telephone number+254 7228724 55 . 